\title{
OLD NORSE PIÓNN AND ITS OLD RUSSIAN RELATIVE TIUN. OR HOW SCANDINAVIAN SERVANTS BECAME EAST SLAVIC BUREAUCRATS
}

\author{
HANA ŠTĚŘÍKOVÁ
}

\begin{abstract}
The Old Russian word $t i(v) u n$ is one of the few medieval loanwords from Old Norse which has been preserved in Russian, Ukrainian and Belarusian to this day. Medieval judicial charters and legal texts from Scandinavia and East Slavic territories show that there was a significant semantic shift around the time of the borrowing process itself: from a name for common unfree servants to the post of a prince's official. Besides, it has gone through quite an extensive semantic development through the centuries both in North Germanic and East Slavic dialects that shows quite remarkable similarities.
\end{abstract}

Keywords: lexical interference; semantic shifts; Old Norse; Old East Slavic; medieval judicial charters; Scandinavian loanwords in Old Russian

The Old East Slavic masculine noun $t i(v) u n$ and its derivatives rank among quite well preserved Scandinavian lexical borrowings in the Old Russian language ${ }^{1}$. They can be even found in present-day East Slavic languages (Russian, Ukrainian and Belarusian), although rather in the form of rarely used archaisms. To this day, these languages reflect two variations: older tiun and younger tivun with the intervocalic consonant $/ \mathrm{v} / .^{2}$ This article discusses the context of this ancient borrowing in the North Germanic legal texts from the perspective of historical semantics.

1 The era of Old Russian or Old East Slavic language is often defined as the language of East Slavic tribes spoken in 11th-13th century and from the historic point of view corresponds with the era of Kievan Rus'. Both for this period and the next historic era of Muscovite Rus' we use the term Old Russian in the sense of the dialect spoken by the East Slavs in the area of various historical formations: Kievan Rus', Muscovite Rus', Grand Duchy of Lithuania and Novgorod Republic (see, e.g., Leška 193f.).

2 In contemporary Russian as noun m. tiun, adjective tiunskij, -aja, -oe (Ožegov - Svedova 799) and less frequent tivun, $-a$ (Ušakov t. 1706 and 718); in contemporary Ukrainian as noun m. tiun, -a, adjective tiuns'kyj, $-a,-e$ (Busel 1455); in contemporary Belarusian as noun m. civun, -a, adjective civunski, -aja, -ae (Sudnik 731). 


\section{Old Russian Administrator and Governor}

The semantic scale of the term ti(v)un in Old Russian is supposed to be quite wide. The lexeme was used in different contexts depending on both time and place: it could stand for general servants or housemen, butlers, special posts at the prince's court or in boyars' or bishops' households, and it was often used for administrators in the local government (of villages, towns or districts), governors or curators (Sreznevskij 961-963). Another definition adds prince's officials, stewards or treasurers (Karskij 91). The position of tiuns in the Old Russian society seems to have been of quite a high importance, but they still represented a class of servants and as such had the status of unfree men (serfs). The persons that were appointed to tiuns became bound even in cases when they were recruited from previously free men (Schaller 318).

The lexeme can be found in Old Russian texts and later East Slavic materials up to the 16 th century. The first records of the word come from the most ancient written datable sources - medieval birch bark letters. The oldest currently known record was found in 1992 at excavation sites in Novgorod in stratigraphic layers from 1120-1150. It's a small oak chart No. 42a /5 38/ with following content:

А AZZ THOYNE

АаNь жь оүАль (Zaliznjak 342)

The inscription can be intepreted as "and I, tiun, have collected taxes" (Zaliznjak 342), or perhaps even "and I collected taxes for the tiun". In either case, it shows an administrative function of a tiun - that of a tax collector.

Other records are probably at least a hundred or more years younger than this, as is the case of the oldest preserved text of the ancient legal code of Kievan Rus' Russkaja pravda (based on the manuscript of a Kormchaia from 1282). It contains both variants with and without the intervocalic $/ \mathrm{v} /$ in altogether six tokens in the whole document. The context does not allow to draw any specific conclusions regarding the particulars of a tiun's occupation, other than that it stood for a man working for privileged persons and that killing of such a man was to be penalized by the second highest fines (40 grivnas). ${ }^{3}$ The noun occurs with attributes showing tiun's subordination to a prince (gen./ acc. sg. “тивінна кнАжА”, Karskij, 27) or to a boyar (“тивүัнъ бонарескъ”, Karskij, 27), and that his post could be even a village administrator (loc. sg. "въ сельскомъ тиоунъ”, Karskij 30).

More light can be shed on the meaning and distribution of this word only with help of later texts - judicial charters and other official documents from the era of Novgorodian Rus', Muscovite Rus' and Grand Duchy of Lithuania. They give evidence of tiuns' exis-

3 A passage from the preamble of Russkaya pravda, stating the penalty for killing of a tiun and other men from the prince's retinue or court: “[А]жь оубьють моужь моужа · то мьстити братоу брата · [...]

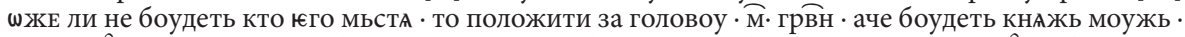
или тивйна кнАЖА · аче ли боудеть роусинъ любо гридь · любо коупець · любо тивйнъ бонрескъ [...] то · М. грӒн положити за нь" (Карский 1930: 26n.) - "If a man kills another man, then a brother shall avenge a brother [...] If there is no one to take revenge, then 40 grivnas shall be paid for the killed, if he is a prince's man or a prince's official's man. If the murdered is a rusin or a grid', or a merchant, or a boyar's official [...] then 40 grivnas are to be paid for him". 
tence in the span of 13 th to 16th century. The following examples from North-Western Rus', counted to be among the oldest, mention the prince's deputies on the posts of his and municipal administrators as representatives within the local government:

“а в Торожку [ти], княже, держати тивунъ на своеи части, а новгородець на своей” (GVPN № 1 [1264]: 9)

"and in Torožok can you, prince, keep a tivun in your part and the Novgorodians [can have one] in theirs". ${ }^{4}$

The Old East Slavic term was generally used for a post of an official in administration of villages, towns, districts or a larger territory. Nevertheless, the most common collocations of the word express subordination to other, higher ranks and seem to refer to the fact, that tiuns held probably lower posts in the local management. The collocations give an impression of set phrases and the only attributes that differ are various specifications of a geographic or an administrative area, such as:

- “волостели мои и ихъ тіуни (АЕ̃ № 23 [1425]: 17; AẼ № 31 [1437]: 24) “my administrators and their tiuns",

- “намЂстницы наши ... и тіуни и волостели Московскіе” (АЁ № 240 [1554]: 256) “our governors ... and tiuns and Moscow administrators".

Tiun posts were common in the Church administration, too, where they carried out management of monasteries and their properties in particular, and sometimes they are mentioned as assistant executive officials in the services of Metropolitans or other high officials in the Orthodox Church, as in: "митрополичи намъстники черные, и ихъ тіуни” (AЀ № 159 [1515]: 129) “governors of our Metropolitans and their tiuns”.

\section{The Origins of the Old Russian tiun}

Etymologists were often groping in the dark when looking for the origins of this unusual word. The linguists who were willing to admit its Germanic connections worked for a long time with the presumption that it had been borrowed from the Gothic language. This was a widely-held belief, particularly in the 19th century, when Gothic was considered to be the oldest known Germanic language. This assumption was also evidenced by the Russian patriotic philologist I. I. Sreznevski, one of the highest authorities in Russian historical linguistics and lexicography, in his treatment of the lexeme ti(v)un. He saw its predecessor in some of the following Gothic words for "servant": pius, pevis or pivan, and he claimed the Old English pëgn > pëgen > pên was then the closest lexical relative of the Russian word (Sreznevskij 963).

The origins of the word were, however, determined more precisely throughout the course of the 20th century. Max Vasmer considered tiun an ancient lexical borrowing from its Old West Norse predecessor pjónn (Vasmer 108; Fasmer 63), in harmony with Clara Thörnqvist's statement that it had been borrowed from Old Swedish * piūn (Thörn-

4 All examples have been translated by the author of this article, unless otherwise stated. 
qvist 87f.), which she then reconstructed. Thörnqvist's explanation of the word's etymology would suggest a perfect phonological correspondence, though there is one little catch: this form can not be found in any of the preserved records of Old Swedish or Old East Norse. The original diphthong /iū/ has long been known from Old West Norse sources only. It has even been preserved in Elfdalian ${ }^{5}$, though only as a part of the triphthong /iuo/ in the weak verb tiuona ("to serve"), which has likely retained the ancient Old Norse dipthong from the early stages before it split into West and East Norse dialects. ${ }^{6}$ The development of the Proto-Germanic diphthong /eu/ > /jo/ > /iuo/ is considered to have been parallel to the development in East Norwegian dialects and can be regarded as a bridge between West and East Norwegian (Levander 45ff.).

If we accept the Elfdalian verb as a testament to Thörnqvist's reconstruction, we might consider that the Old Russian $t i(v)$ un finally has got a verifiable etymology. From the phonological point of view it would reflect the Old Norse form with the vowel /i/ in its root morpheme. This vowel was originally a part of the ascending Old Norse diphthong /iu/ that developed already in the Proto-Norse era from the Proto-Germanic diphthong /eu/ and was later lengthened and became /iū/ (and then /jū/) during various assimilation processes (Noreen 40). The most likely North Germanic lexical predecessor of the word would then be the root morpheme ${ }^{\star}$ peun- (derived from the Proto-Germanic ^pewa- "to serve") (Uhlenbeck 151; Thörnqvist 88; Kroonen 541), which is well reflected in present-day Scandinavian languages: Icelandic pjónn "servant, slave" and péna "to serve" (cf. Faroese tjena), Swedish tjäna "to serve" (cf. Old Swedish piǣna below) or Danish tjene (Árnason 1208, Hellquist 983). The Icelandic and Old West Norse pjónn can be simply derived from the Old Norse verb pjá "to enslave someone" as a deverbative (a former participle), which in turn can be derived from the Proto-Germanic verb * pewna with the root-morpheme ${ }^{\star}$ pew- / ${ }^{\star}$ peu- $>{ }^{\star}$ pegw- I ${ }^{\star}$ pehw- (Magnússon 1183). The Proto-Germanic root is closely connected to a number of other expressions for servants and slaves in North Germanic languages, like Old West Norse pír and $p y^{\prime}$ "female slave" and the compound elements - pér, -pjófr and *-pýr (>-tyr), or in Old Swedish pybarn "illegitimate child, bastard” (e.g. a child born to a female slave), Old Gutnish pysun "illegitimate son" and others (Brink 126ff.). Other parallels can be found, for instance, in the Old English péowen/ðéowen "maid, slave girl", Old Low German thionōn "to serve" and thionost "service" or Old High German deo "servant" (Hellquist 983; Magnússon 1183; de Vries 614).

The origin of the above mentioned Proto-Germanic root was long regarded as the Indo-European word stem *tekw "to run". 7 Then, the deverbative noun would bear semantics of "someone who is running around (and serving somebody or doing errands)" or "someone who is coming". Even though this theory has been questioned again quite recently by Kroonen, who pointed out a possible link to an unspecified Indo-European adjective with primary meaning "bound, unfree, tamed" (Kroonen 541), the seman-

5 Elfdalian or Övdalian - ulum dalska, is an ancient branch of the Swedish Dalecarlian dialects, spoken in the locality of Älvdalen in central Sweden.

6 The verb occurs in another variant with the mid-front vowel tiuäna; cf. Swedish tjäna (Åkerberg 262; Steensland 210 and 461).

7 Cf. Sanskrit tákti, Lithuanian tekéti or Proto-Slavic *tekti and Old Church Slavonic тешти (Vasmer 89; Kroonen 541). 
tics indicate that it might be a very valid explanation after all, as there is a group of Indo-European terms for servants and slaves with an analogous semantic development that has been reflected, besides others, in the older North-Germanic lexicon (e.g. ambótt or griðmaðr).

\section{The North Germanic Relative and Predecessor}

The Old West Norse masculine noun piónn "servant, slave" is likely a derivative of the verb pióna "to serve, to attend to", which in turn is presumed to be derived from the Proto-Norse ${ }^{\star}$ pewna, while the Proto-Germanic ${ }^{\star}$ pewa probably vanished as a separate lexeme already in the old North Germanic dialects (Wissmann 7). The scarce Proto-Norse Runic inscriptions have preserved only a masculine noun $p e w a R^{8}$, a form known as the last component in compound male names like Wulpupewar (Brink 154). The following example has been found on an amulet made of deer horn from the 6th century at the archeological site Sorte Muld (location Ibsker on Bornholm). The inscription DK Bh 46 was carved in Elder Futhark and its transliteration is:

$$
\begin{aligned}
& \text { balika ar- } \ldots \mid \ldots \text { (f)ular pewar }{ }^{9} \\
& \text { perhaps: "Balika ... } \mid \text {...'s servant". }
\end{aligned}
$$

Because of its fragmentary character, the meaning of the text is quite unclear. We can only guess that it refers to a male called Balika, who might have been a servant or just a companion to another male, whose name ended with -fular. Another illustration from a complete, but still very short Runic inscription N KJ55 U, found on the Valsfjord cliff in central Norway, was carved in Elder Futhark as well, probably around year 400 (Düwel 34). A possible interpretation of the noun is "manservant" or "follower" as well (Antonsen 227):

ek hagustald(a)z țewaz godagas $\mid(e)------z^{10}$

"I, Hagustaldar, follower of Godag” or “I, Hagustaldar, Godag's servant”.

In the oldest manuscripts (until 1250, including texts of religious character) of the Old West Norse writings from today's Norway, no forms of the root morpheme with a front vowel have been preserved. Only variants with the ancient diphthong /iō/ can be found, including (but not limited to) the verb pióna "to serve", the feminine nouns piónan and piónasta "female servant, slave girl", the masculine nouns piónn and piónastomaðr "servant, slave" (Holtsmark 645f.). In the legal codes of medieval Norway, these words occur mostly in connection with the Christian service and Church laws and regulations, but they still express the general semantic content of "serving to another person (or entity)".

\footnotetext{
8 "Servant", to be understood especially in the cultic and ritualistic sense of the word, but even as a profane serving staff or a companion (Düwel 35).

9 Inscription DK Bh 46. Danske Runeindskrifter [online] http://runer.ku.dk/VisGenstand .aspx?Titel=Sorte_Muld-amulet [cit. 10.07.2018].

10 Inscription N KJ55 U. Samnordisk runtextdatabas [online] http://www.nordiska.uu.se/forskn/samnord .htm [cit. 11. 07. 2018].
} 
This can be illustrated with the following examples from Gulathing Law and Frostathing Law that both mention the nouns pionn "slave" and pionosto "service":

- Gulathing Law, article no. 198:

"Tvær ero hans hinar bezto ambatter. Seta. oc deigia. oc tveir prælar. pionn oc bryti." (NGL I 70)

"Two bondwomen are counted as the best, the housemaid and the housekeeper. Two thralls are counted the best, the foreman and the master's personal servant." (ENL 144);

- Gulathing Law, article no. 9:

"En ver hafum sva mælt við biscop várn. at hann scal oss pionosto veita. En ver scolom pat at hanom kaupa ærtog firi .xl. nevia innan laga varra. En biscop scal fe sva oðrlasc at hann scal koma i fylki hvert a .xii manaðom. oc veita monnom pa pionosto er til byriar" (NGL I 7).

"We"1 have entered into this agreement with our bishop that he shall provide us with divine services. And we shall buy these [services] from him [with an] ertog for every forty persons within our law ${ }^{12}$. And the bishop shall earn this money in this way, that he shall come into every fylki once in a twelvemonth to render such services to the folk as are fit and needful" (ENL 41);

- Frostathing Law, article no. 10:

"En ef grafner værða at nauðgum forræðis monnum pa stande kirkian pionostu laus til pess er kirkiu soknar mænn flytia pa brott” (NGL I 134).

"And if they are buried [in a churchyard] contrary to the wishes of those in charge, that church will stand without services until the parish men shall have moved their bodies away" (ENL 230);

- Frostathing Law, article no. 11:

"Byskup skal raða kirkium oc kristnum dome allum oc kænni mænn til setia pa er hann uil. oc hæfir oss pui hæitit at ver skolum hafa pa kænni mænn er oss pockazt oc pa er kunni pionosto sina retta. pat er forn rettr" (NGL I 135).

"The bishop shall govern the churches and rule in all matters of religion. He shall appoint as priests whomever he will, but he has promised that we shall have such priests as are agreeable to us and [who] know the ritual correctly. That is old law" (ENL 231).

In East North-Germanic medieval texts, many variants of the weak verb piǣna "to serve" (with a wide semantics) with a front root vowel have been recorded, such as piena, piana/thiana, pyäna/tyäna, thena, tene. A number of nominal derivatives of this verb are known from Old Swedish and Old Danish: masculine noun piänare "servant" (variants: thienare, thienere, tiänare, tyänare, tyenare), feminine noun piänist "service" (variants: pienist, pianist, thianasth, pyänist, thiänest, tenisth, thienst, tienst) and thiänirska "female servant" (variants: tiäniska, Old Danish tiänerske), adjective piänogher

11 We stands for the king.

12 Within our law means that this applied to areas within the jurisdiction of the Gulathing. 
"serving, duteous, subordinate" (var. pänoghar, piänugher etc.) and many more, including a rich variety of compounds. ${ }^{13}$

The etymology of piǣna (piāna/piēna/thēna) with the long open root vowel / $\overline{\mathfrak{x}} /$ or $/ \bar{a} /$ is very complicated and blurred within the phonological development of North-Germanic. Hellquist believed that these forms might have been influenced by some of the continental Germanic dialects. He mentioned especially Old Frisian and Old Low German that both had a form with the diphthong /ia/. According to his conclusions, the same phonological process must have been applicable to the Icelandic péna, that he derived from Old English pénian (Hellquist 983). Noreen regarded the change piāna > piēna as a result of the progressive i-mutation (i-umlaut) that was characteristic for the Old Swedish dialects (Noreen 91). However, none of the etymologists have formulated any resolution at all for the preceding vowel lowering from /iū/ to /iā/. An alternative can be found by Fischer, who considered the Old Norse forms péna, pénusta and pénari to be younger borrowings from the Middle Low German dialects, that is from dênen, dênst and dêner (Fischer 42). These forms must have joined and merged with the older variants with / $i \bar{o} /$ due to their close morphology and similar semantic content. Sources for a more precise explanation of these forms are lacking though.

Nevertheless, the Low German influence in the given period of time should not be underestimated and Fisher's theory seems relevant even because the forms with a front vowel first appeared in East North Germanic where the continental culture flows were strongest. Another argument speaking for this theory is that the forms with a front vowel appearing in the North Germanic medieval sources mostly in texts that engaged with Christian themes and dealt with subjects connected to the Church. This was actually the main domain of German influence in Scandinavia in the times when Christianity was being established in the area. The presence of these forms is much more striking in liturgical texts, in translations of legends of saints, but even in charters and other documents on monastery administration and management etc. ${ }^{14}$

The occurrence of these derivatives in East Scandinavian medieval provincial laws is, however, quite sporadic and the root morpheme always contains the front vowel (piǣ $n$-). The most frequented were: the feminine noun pionist "service", the compound masculine noun pionistuman "servant" (literally "man of service") and the verb pionoe "to serve", all of them in both religious and secular contexts. A considerable distribution can be found only in the Uppland law, as illustrated by the following examples:

- "Nu a præstær fore piænist sinæ allæ quikæ tyund" (UL 31).

"The priest shall be given tithe of all livestock for his services";

- "Pa a han aff ærki biskupi. ok lybiskupum. til krunu wighiæs .i. upsalæ kirkiu. sipæn ær han skyldughær kunungær wæræ ok krunu bæræ. [...] pa ma han piænistumannum sinum læn giwæ. Værpær han gopær kunungær. pa lati gup han længi liwæ" (UL 89).

13 See Fornsvensk lexikalisk databas [online] under the articles piäna, piänare, piänist, thiänirska, piänogher, https://spraakbanken.gu.se/fsvldb [cit. 08. 02. 2018] and Noreen 451.

14 See Fornsvensk lexikalisk databas [online] under articles piäna, piänare, piänist, https://spraakbanken .gu.se/fsvldb [cit. 11. 07. 2018]. 
"Then he shall be crowned by the archbishop and subordinate bishops. Then he shall have the authority to become king and wear the crown. [...] And then he may give fieff to his men of service. God may preserve him, if he is a good king";

- "wærpær kununx rapmanz piøenistuman dræpin. ællr ok andræ riddæræ. sæx markær pokkæ bot at. pænni pokki kombær æi .j. utæn .j. drapum. han a takæ hærræ pæs sum dræpin ær" (UL 151).

"If a servant of the king's counsellor or of another lord is killed, then 6 marks shall be paid for him. This fine applies only in the case of killing and it shall be paid to the master of the killed man."

- "Hwar sum lænsman ællr pioenistuman. brytær .i. lagh wip bondæ. söki swa han. sum bonde bondæ" (UL 265).

"If a vassal or a man of service breaks the law against a free man, then [the aggrieved] may charge him just like another free man".

The Younger Westrogothic law in turn demonstrates two possible interpretations for what was understood as secular service. It could be both a service in the broader sense (to a master, a lord or the king) or military service:

- "Wil man sinum swene æller frænðæ. ællr huen han vil iorb giua. giui af köpo iorpum. ok pa han hauir fangit .i. herre pionist æn eig af fæperni æller moperni ællr arftakin iorp num arfui vili" (WgL 159).

"If a man wants to give land to his servant or relative or to anyone he wishes, then he may give him land that he bought or gained in service to a lord, but not land that he obtained from his father or mother or inherited, if it is not the heir's will";

- "Holgkin leghomaper möllæri. almennigx bönder æller bondæ sun vgipter vr garpi bær stikæmez. per eig æru piænistu men. æller .i. vandræpum. böten. III. sextan örtugher” (WgL 211).

"If a soldier, a miller, a common farmer or farmer's son carries a sword, then he shall pay three times 16 ertogs, if he is not in [the king's] service ${ }^{15}$ or under threat".

The last example comes from the Dalecarlian Law and illustrates the use of the feminine noun picenst in the meaning of service as labour for a landowner, e.g. on his farm or on his lands:

_ "Hwilikis manz swen takir hö ella korn ella annat nokot gen bondans wilia. hawi till witni twa sina granna at swa war giort. pa skal han kæra pæt firi hans husbonda. han skal pæt attir giældæ. ella affsighis sweninum. ær han driuari ella piøensto lös. halde bondin wp han" (DL 57).

"If someone's servant takes hay or grain or something else without the farmer's permission, then he must have two neighbours as witnesses. Then he can bring a charge by the [servant's] master who shall compensate the damage or get rid of the servant. If he is a wage worker or a man without permanent service, then the farmer shall detain him."

15 E.g. in the military. 


\section{Semantic Shifts as a Reflection of the Development of a tiun's Tasks}

The Old Russian word $t i(v) u n$ contains the original, ancient diphthong /iü/, which is preserved only in Old West Norse sources, although the commonly accepted locality of the Scandinavian influence on East Slavs is East Central Scandinavia. ${ }^{16}$ This means that the time of borrowing into Old Russian must have been very early, since it has conserved the diphthong form from the time before dissimilation in East and West Scandinavia and before the articulation shift of the diphthong to the front East variant /i $\bar{x} /$. Therefore it must have happened before the end of the 10th century, during the earlier phase of the Old Norse era. The original long Old Norse diphthong /iū/ is reflected in two syllables with the intervocalic consonant $/ \mathrm{v} /$, which is typical for the oldest East Slavic inscriptions. The intervocalic $/ \mathrm{v} /$ resembles one of the supporting consonants, which typically appears in vowel clusters to restrict hiatus in East Slavic languages.

There was quite a significant semantic shift which occured either during the borrowing process or at an early stage of lexicalization in Old Russian. $T i(v)$ uns executed higher posts within the Old Russian legal and administrative hierarchy and were members of a group then called княжие люди - the prince's men. As such, they had command over certain administrative matters and enjoyed special privileges, including legal protection by the prince himself. The lexical equivalent in medieval Scandinavian laws did not evoke such dignity and power, at least not in the early stages. The Old Norse predecessor of tiun belonged to ancient Germanic terms for unfree persons (ofrelse moen), who were held as property of free (and born as free) persons (freelse moen). According to the oldest known Germanic concepts, the unfree men were tangible property, just like domestic animals or household equipment. ${ }^{17}$ This basic terminology was gradually diversified and included many more words for servants and other subordinate subjects, which later went through a varied, sometimes even dramatic semantic development with a manifold of local variations. The semantic shift in Old Russian happened most likely in the second half of the 10th century during the reign of Princess Olga, who strived to centralize the power over Rus' and actually created a structured administrative organization of the territory. The original minions from the prince's crew - who were still unfree men, too - got then more or less determinate tasks and functions and thus became officials in public service. However, the Scandinavian sources show a very similar trend in their semantic development, although the results differ to a certain extent, as demonstrated above: from a simple unfree worker to a king's servant, soldier or servant of God..$^{18}$

${ }^{16}$ Likely from the south-east part of the present-day Swedish province Uppland, once called Roden (see Larsson - Fridell; Melnikova - Petrukhin and others).

17 Servants were often generally described only as men in the Old Germanic laws and their owners counted the numbers of their staff by "heads", just like they did with livestock - cf. Old High German manahoubit (von Amira 35).

18 This work was supported by the European Regional Development Fund-Project "Creativity and Adaptability as Conditions of the Success of Europe in an Interrelated World" (No. CZ.02.1.01/0.0/0. 0/16_019/0000734). 


\section{BIBLIOGRAPHY}

Åkerberg, Bengt. Älvdalsk grammatik. Älvdalen: Ulum Dalska, 2012.

von Amira, Karl. Germanisches Recht. Bd. II: Rechtsaltertümer. 4. Auflage. Berlin: De Gruyter, 1967.

Antonsen, Elmer H. Runes and Germanic Linguistics. Berlin: Mouton de Gruyter, 2002.

Árnason, Mörður. Íslensk orðabók. Reykjavík: Edda, 2007.

Brink, Stefan. Vikingarnas slavar. Den nordiska träldomen under yngre järnålder och äldsta medeltid. Stockholm: Atlantis, 2012.

Busel, Vjačeslav Tymofijovyč. Velikij tlumačnij slovnik sučasnoï ukraïnskoï movi. Kiïv: Perun, 2009.

Fasmer, Max. Ėtimologičeskij slovar' russkogo âzyka IV. Moskva: Progress, 1987.

Fischer, Frank. Die Lehnwörter des Altwestnordischen. Berlin: Mayer \& Müller, 1909.

Hellquist, Elof. Svensk etymologisk ordbok. Lund: Berlingska boktryckeriet, 1922.

Holtsmark, Anne. Ordförrådet i de eldste norske håndskrifter til ca. 1250. Oslo: J. Dybwad, 1955.

Kroonen, Guus. Etymological Dictionary of Proto-Germanic. Leiden - Boston: Brill, 2013.

Larsson, Mats G. and Fridell, Stefan. "Roden och jarlen." Namn och bygd. Tidskrift för nordisk ortnamnsforskning 102 (2014), 51-68.

Leška, Oldřich. Jazyk ve strukturním pojetí. Kapitoly ze synchronní a diachronní analýzy ruštiny. Prague: Slovanský ústav, 2003.

Melnikova, E. A. and Petrukhin, V. J. “The Origin and Evolution of the Name 'Rus': the Scandinavians in Eastern-European Ethno-Political Processes before the 11th Century." Tor 23, (1990/1991), 203-234.

Levander, Lars. Dalmålet. Beskrivning och historia. D. I. Uppsala: Appelberg, 1925.

Magnússon, Ásgeir Blöndal. Íslensk orðsifjabók. Reykjavík: Orðabók Háskólans, 2008.

Noreen, Adolf. Altisländische und altnorwegische Grammatik. Unter Berücksichtigung des Urnordischen. Halle: Max Niemayer, 1884.

Noreen, Adolf. Altschwedische Grammatik: mit Einschluss des Altgutnischen. Halle: Max Niemayer, 1904. Ožegov, S. I. and Švedova, N. Û. Tolkovyj slovar' russkogo âzyka. Izd. 4-oe. Moskva: Vysšaâ škola, 2004.

Schaller, H. W. et al. Real- und Sachwörterbuch zum Altrussischen. Neuried: Hieronymus Verlag, 1985.

Sreznevskij, I. I. Slovar' drevnerusskogo âzyka. Moskva: Kniga, 1989. (1st edition in 1890-1912 as Materialy dlâ slovarâ drevne-russkago âzyka po pis'mennym pamâtnikam)

Steensland, Lars. Material till en älvdalsk ordbok. Älvdalen: Ulum Dalska, 2010.

Sudnik, M. R. Tlumačaĺny sloŭnik bielaruskaj litaraturnaj movy. Minsk: Belaruskaâ èncyklapedyâ, 1996.

Thörnqvist, Clara. Studien über die nordischen Lehnwörter im Russischen. Uppsala - Stockholm: Almqvist \& Wiksell, 1948.

Uhlenbeck, C. C. "Die germanischen Wörter im Altslawischen." Archiv für slavische Philologie 15, 1893, 481-492.

Ušakov, D. N. Tolkovyj slovar' russkogo âzyka. Moskva: Sovetskaâ ènciklopediâ, 1935-1940.

Vasmer, Max. Russisches etymologisches Wörterbuch, T. III. Heidelberg: Carl Winter, 1958.

de Vries, Jan. Altnordisches etymologisches Wörterbuch. Leiden: Brill, 1962.

Wissmann, Wilhelm. Die altnordischen und westgermanischen Nomina postverbalia. Heidelberg: Carl Winter, 1975.

Zaliznjak, A. A. Drevnenovgorodskij dialekt. Izd. 2-e, pererabotannoe s učëtom materiala naxodok 1995-2003 gg. Moskva: Âzyki slavânskoj kultury, 2004.

\section{PRIMARY SOURCES}

AÊ: Akty, sobranye v biliotekax i arxivax Rossijskoj imperii arxegrafičeskoju èkspedicieju Imperatorskoj akademii nauk. Sankt-Peterburg: Tipografiâ II Otdeleniâ Sobstvennoj E. I. V. Kancelârii, 1836.

Danske Runeindskrifter [online] http://runer.ku.dk.

DL: Dalalagen (Äldre Westmannalagen). In: Schlyter, J. [ed.]: Samling af Sweriges gamla lagar, bd. 5. Lund: Berlingska boktryckeriet, 1851. 
ENL: The Earliest Norwegian Laws: Being the Gulathing Law and the Frostathing Law. Transl. by Laurence M. Larson. New Jersey: The Lawbook Exchange, 2008.

Fornsvensk lexikalisk databas [online] https://spraakbanken.gu.se/fsvldb.

GVPN: Gramoty Velikogo Novgoroda i Pskova. Moskva - Leningrad: Izdatel'stvo Akademii nauk SSSR, 1949.

Karskij, E. F. [ed.]: Russkaja Pravda po drevnejšemu spisku. Leningrad: Izdatel'stvo Akademii nauk, 1930, 26-62.

NGL: Norges gamle love indtil 1387. Bd. I-II. Keyser, R., Munch, P. A. [ed.]. Christiania: C. Gröndahl, 1846-1848.

Samnordisk runtextdatabas [online] http://www.nordiska.uu.se/forskn/samnord.htm.

UL: Uplandslagen. In: Schlyter, J. [ed.]: Samling af Sweriges gamla lagar, bd. 3. Stockholm: P. A. Norstedt \& Söner, 1834.

WgL: Westgötalagen. In: Collin, S. - Schlyter, J. [eds.]: Samling af Sweriges gamla lagar, bd. 1. Stockholm: Z. Haeggström, 1827.

\section{Hana Štěříková}

Charles University

E-mail: hana.sterikova@ff.cuni.cz 